University of Nebraska - Lincoln

DigitalCommons@University of Nebraska - Lincoln

Faculty Papers and Publications in Animal

Science

Animal Science Department

2000

\title{
Effect of Dietary Concentration of Metabolizable Lysine on Finishing Cattle Performance
}

\author{
M. J. Klemesrud \\ University of Nebraska-Lincoln \\ Terry J. Klopfenstein \\ University of Nebraska-Lincoln, tklopfenstein1@unl.edu \\ Rick Stock \\ University of Nebraska-Lincoln, rstock3@Unl.edu \\ Austin Lewis \\ University of Nebraska-Lincoln, alewis2@unl.edu \\ D. W. Herold \\ University of Nebraska-Lincoln
}

Follow this and additional works at: https://digitalcommons.unl.edu/animalscifacpub

Part of the Animal Sciences Commons

Klemesrud, M. J.; Klopfenstein, Terry J.; Stock, Rick; Lewis, Austin; and Herold, D. W., "Effect of Dietary Concentration of Metabolizable Lysine on Finishing Cattle Performance" (2000). Faculty Papers and Publications in Animal Science. 529.

https://digitalcommons.unl.edu/animalscifacpub/529

This Article is brought to you for free and open access by the Animal Science Department at DigitalCommons@University of Nebraska - Lincoln. It has been accepted for inclusion in Faculty Papers and Publications in Animal Science by an authorized administrator of DigitalCommons@University of Nebraska - Lincoln. 


\title{
Effect of dietary concentration of metabolizable lysine on finishing cattle performance
}

\author{
M. J. Klemesrud, T. J. Klopfenstein ${ }^{2}$, R. A. Stock, A. J. Lewis, and D. W. Herold \\ Department of Animal Science, University of Nebraska, Lincoln 68583-0908
}

\begin{abstract}
A finishing trial and a metabolism trial were conducted to determine the effect of supplemental metabolizable Lys level on finishing calf performance and to estimate the metabolizable Lys requirement of finishing calves. The finishing trial included 60 individually fed crossbred beef steer calves $(237 \mathrm{~kg} ; \mathrm{SD}=20$ $\mathrm{kg}$ ) supplemented with either incremental amounts of rumen-protected Lys and Met, or Met alone. Addition of Lys and Met improved gains and efficiencies (quadratic; $P<.02$ ) during the first $56 \mathrm{~d}$. There was no response to supplemental Met alone, suggesting that supplemental Lys rather than Met was responsible for the improvement in performance. Using nonlinear analyses to compare gain relative to supplemental Lys intake, maximum gain was determined to be $2.10 \mathrm{~kg} /$ $\mathrm{d}$, or . $27 \mathrm{~kg} / \mathrm{d}$ above the zero Lys control, at a supplemen-
\end{abstract}

tal Lys intake of $2.56 \mathrm{~g} / \mathrm{d}$. Steers supplemented with 3 and $4 \mathrm{~g}$ of Lys had a weight advantage over the control steers of $16 \mathrm{~kg}$ at $56 \mathrm{~d}$ and $32 \mathrm{~kg}$ at the end of the 161$\mathrm{d}$ trial. However, there were no statistical responses to Lys or Met during any periods after $56 \mathrm{~d}$. During a separate metabolism trial, four steers fed the control finishing diet were slaughtered, and abomasal contents were collected for amino acid analyses. The predicted (Level 1 NRC, 1996) metabolizable protein flow to the abomasum for the control diet was $715 \mathrm{~g} / \mathrm{d}$, and the predicted Lys flow was $37.9 \mathrm{~g} / \mathrm{d}$. A supplemental Lys intake of $2.56 \mathrm{~g} / \mathrm{d}$ would increase the Lys flow to 40.5 $\mathrm{g} / \mathrm{d}$. Feedlot diets low in ruminal escape protein may be deficient in metabolizable Lys, especially early in the feeding period. The metabolizable Lys requirement of steer calves gaining $2.10 \mathrm{~kg} / \mathrm{d}$ is estimated to be 40.5 $\mathrm{g} / \mathrm{d}$.

Key Words: Beef Cattle, Lysine, Protein, Amino Acids

(C)2000 American Society of Animal Science. All rights reserved.

J. Anim. Sci. 2000. 78:1060-1066

\section{Introduction}

Large-framed calves finished directly after weaning make rapid and efficient gains, depositing a large percentage of protein as lean tissue (Byers and Rompala, 1980). These calves have high metabolizable protein (MP) requirements that may exceed their supply of MP from microbial and dietary escape protein. Supplementing with escape protein when MP is limiting has improved feed efficiency, especially early in the feeding period (Sindt et al., 1993a).

Wet corn gluten feed and high-moisture corn, two ingredients used widely in finishing diets, are poor sources of escape protein compared with dry corn (26 and $38 \%$ of CP, respectively, compared with $65 \%$ of $\mathrm{CP}$ for dry-rolled corn; Firkins et al., 1984; Sindt et al., 1993b). Because grain protein constitutes the major

\footnotetext{
${ }^{1}$ Published with the approval of the director as paper no. 12469, journal series, Nebraska Agric. Res. Div.

${ }^{2}$ To whom correspondence should be addressed.

Received February 6, 1999.

Accepted September 29, 1999.
}

portion of the total escape protein intake of cattle finished with high-grain diets, finishing diets containing wet corn gluten feed and high-moisture corn may be deficient in MP. However, response to escape protein supplementation has been variable for finishing cattle fed wet corn gluten feed and high-moisture corn (McCoy et al., 1998; Richards et al., 1998).

Methionine and Lys seem to be the two amino acids limiting growth in microbial protein (Nimrick et al., 1970; Williams and Smith, 1974; Komarek et al., 1983). To be effective, escape protein should, therefore, supply adequate amounts of these two amino acids. However, corn protein, the major source of escape protein in finishing diets, is a poor source of Lys, which seems to be the first-limiting amino acid for $\mathrm{N}$ retention (Hill et al., 1980; Titgemeyer et al., 1988).

This research was conducted to determine the effect of supplemental metabolizable Lys amount on finishing calf performance and to estimate the metabolizable Lys requirement of finishing calves.

\section{Materials and Methods}

Finishing Trial. A calf finishing trial was conducted to test the effect of supplemental metabolizable Lys 
level on feed intake, daily gain, and feed efficiency. Sixty large-framed crossbred beef steer calves $(237 \mathrm{~kg}$; $\mathrm{SD}=20 \mathrm{~kg}$ ) were used in a completely randomized design. Treatments consisted of either nine incremental levels of rumen-protected Lys and Met or rumen-protected Met alone. The levels of Lys from rumen-protected Lys were $0,1,2,3,4,6,8,10$, and $12 \mathrm{~g} / \mathrm{d}$. Because the source of rumen-protected Lys also contained rumen-protected Met (Smartamine ML; Rhône-Poulenc Animal Nutrition, Atlanta, GA), these amounts of Lys corresponded with $0, .3, .6, .9,1.2,1.8,2.4,3.0$, and 3.6 $\mathrm{g} / \mathrm{d}$, respectively, of rumen-protected Met.

To determine whether any response was due to Lys rather than Met, an additional treatment of rumenprotected Met alone (Smartamine M; Rhône-Poulenc Animal Nutrition) was included. The level of Met from rumen-protected Met for this treatment was $3.6 \mathrm{~g} / \mathrm{d}$, or equal to the highest level of Met in the Lys and Met combination. These products contained Lys and Met, or Met alone, encapsulated in a $\mathrm{pH}$-sensitive coating (poly-2-vinyl-pyridine-co-styrene), which is stable at a ruminal $\mathrm{pH}$ of 5.4 yet loses its integrity when it enters the abomasum (Polan et al., 1991). Steers were assigned randomly to treatment, with 10 steers on the negative control and the Met control treatments and five steers on each of the other eight treatments.

Steers were fed individually once daily using Calan electronic gates (American Calan, Northwood, NH). Diets consisted of $45 \%$ wet corn gluten feed, $22.5 \%$ highmoisture corn, $20 \%$ dry-rolled corn, $5 \%$ corn silage, $5 \%$ alfalfa hay, and $2.5 \%$ supplement (DM basis, Table 1) and were formulated to contain a minimum of $12 \%$ crude protein, . $7 \% \mathrm{Ca}, .35 \% \mathrm{P}$, and $.7 \% \mathrm{~K}$. Supplements were combined at feeding to make up the 10 treatments, which varied in amount of supplemental rumen-protected Lys and Met. Supplements also provided $28 \mathrm{mg} /$ $\mathrm{kg}$ daily of monensin sodium (Elanco Animal Health, Indianapolis, IN) and $9 \mathrm{mg} / \mathrm{kg}$ tylosin (Elanco Animal Health).

For $7 \mathrm{~d}$ before the start of the trial, steers were limitfed $5.5 \mathrm{~kg} / \mathrm{d}$ (DM basis) of a diet containing 50\% corn silage and $50 \%$ alfalfa hay to reduce weight differences due to reticuloruminal fill. Initial weights were the average of three weights taken before feeding on consecutive days at the start of the trial. Weight data were also collected for $d 56,84$, and 112 of the trial using the average of three weights taken on consecutive days. Final weights $(161 \mathrm{~d})$ were based on carcass weights divided by .62. Interim weights were shrunk 4\% (NRC, 1996). Steers were implanted with Revalor-S (HoechstRoussel, Somerville, NJ) at the start of the trial and again on d 84.

Steers were adapted to the final finishing diet by limit-feeding the final diet on $\mathrm{d} 1$ starting at $5.5 \mathrm{~kg} / \mathrm{d}$ (DM basis) and increasing the amount offered by .45 $\mathrm{kg}$ (DM basis) daily until animals were offered sufficient feed for ad libitum consumption. Feed refusals were collected and weighed every $3 \mathrm{~d}$ to keep feed fresh and bunks clean. At the conclusion of the trial, steers were
Table 1. Composition of diets (\%, DM basis) fed to finishing steers

\begin{tabular}{|c|c|c|c|}
\hline \multirow[b]{2}{*}{ Ingredient } & \multicolumn{3}{|c|}{ Supplemental amino acid treatment } \\
\hline & $\begin{array}{l}0 \text { Lys, } \\
0 \text { Met }^{\text {a }}\end{array}$ & $\begin{array}{l}\text { 12 Lys, } \\
\text { 3.6 } \text { Met }^{\mathrm{a}}\end{array}$ & $\begin{array}{c}0 \text { Lys, } \\
\text { 3.6 Met }\end{array}$ \\
\hline Wet corn gluten feed & 45 & 45 & 45 \\
\hline High-moisture corn & 22.5 & 22.5 & 22.5 \\
\hline Dry-rolled corn & 20 & 20 & 20 \\
\hline Corn silage & 5 & 5 & 5 \\
\hline Alfalfa hay & 5 & 5 & 5 \\
\hline Dry supplement & 2.5 & 2.5 & 2.5 \\
\hline Limestone & 1.49 & 1.49 & 1.49 \\
\hline Finely-ground corn & .58 & .29 & .52 \\
\hline Salt & .3 & .3 & .3 \\
\hline Trace mineral premix ${ }^{b}$ & .02 & .02 & .02 \\
\hline Vitamin premix ${ }^{c}$ & .01 & .01 & .01 \\
\hline Rumensin premix ${ }^{\mathrm{d}}$ & .02 & .02 & .02 \\
\hline Tylan premix & .01 & .01 & .01 \\
\hline Thiamin premix ${ }^{f}$ & .01 & .01 & .01 \\
\hline Copper oxide & .01 & .01 & .01 \\
\hline Tallow & .05 & .05 & .05 \\
\hline Smartamine $\mathrm{ML}^{\mathrm{g}}$ & - & .29 & - \\
\hline Smartamine $\mathrm{M}^{\mathrm{h}}$ & - & - & .06 \\
\hline Dietary CP, \% of $\mathrm{DM}^{\mathrm{i}}$ & 11.9 & 11.9 & 11.9 \\
\hline
\end{tabular}

${ }^{\text {a}}$ Diets mixed at feeding to provide $0,1,2,3,4,6,8,10$, or $12 \mathrm{~g} / \mathrm{d}$ of supplemental Lys.

${ }^{\mathrm{b}}$ Contains $10 \% \mathrm{Mg}, 6 \% \mathrm{Zn}, 2 \% \mathrm{Mn}, 4 \% \mathrm{Fe}, .5 \% \mathrm{Cu}, .3 \% \mathrm{I}$, and $.05 \%$ Co.

${ }^{\mathrm{c}} 15,000 \mathrm{IU}$ of vitamin A, 3,000 IU of vitamin D, and $3.75 \mathrm{IU}$ vitamin $\mathrm{E}$ per gram of premix.

d $176 \mathrm{~g}$ monensin/kg premix (Elanco Animal Health, Indianapolis, IN).

e88 g tylosin/kg premix (Elanco Animal Health).

${ }^{\mathrm{f}} 18 \mathrm{~g}$ thiamin/kg premix.

${ }^{g}$ Contains 50\% Lys and 15\% Met (Rhône-Poulenc Animal Nutrition, Atlanta, GA).

${ }^{\mathrm{h}}$ Contains $70 \%$ Met (Rhône-Poulenc Animal Nutrition).

${ }^{i}$ Based on actual $\mathrm{CP}$ values of ingredients.

slaughtered. Following a 48-h chill, USDA quality and yield grades and fat thickness at the 12th rib were collected.

Blood was drawn by jugular venipuncture from all steers before feeding on d 28, 56, and 140. Blood was placed on ice until it was centrifuged at $5,000 \times g$ for $20 \mathrm{~min}$. Three milliliters of plasma from each calf was deproteinized with $90 \mathrm{mg}$ of sulfosalicylic acid for plasma amino acid analysis (AOAC, 1984) using ionexchange chromatography with HPLC (Waters, Milford, MA).

Animal performance was statistically analyzed two ways. The first analysis was analysis of variance as a completely randomized design using the GLM procedure of SAS (1985). Steer was the experimental unit. There were three objectives for this analysis 1 ) determine whether the methionine control was different from the 0 Lys control; 2) determine whether there was a significant treatment effect (response to Lys); and 3) determine the type of response (linear, quadratic, or cubic). The model included amino acid amount and the residual was the error term. Orthoganol contrasts, corrected for unequal spacing, were used to make the previously mentioned comparisons. Data were analyzed 
for repeated measures using GLM procedures (SAS, 1985), but no treatment $\times$ time interactions were detected $(P>.05)$.

When a significant treatment effect was obtained but no difference was observed for Met vs 0 Lys, then the latter two treatments were combined and the data were subjected to nonlinear analysis (NLIN; SAS, 1985) as described by Klopfenstein et al. (1985). Supplemental Lys level was the independent variable and both ADG and gain:feed ratio were used as the dependent variables.

Individual plasma amino acid concentrations were also plotted against supplemental Lys intake. The NLIN procedure of SAS (1985) was used to find the breakpoint in plasma concentration of Lys with no initial response to supplemental Lys followed by a positive slope. Such a response is characteristic of a limiting amino acid (Gibb et al., 1992). Essential amino acids with an initial negative response followed by a plateau were also analyzed for a breakpoint. Such a pattern may identify amino acids that became limiting.

Metabolism Trial. The amino acid composition of the protein present at the abomasum was determined in a separate metabolism trial. Four steers were fed the control diet from the finishing trial for $14 \mathrm{~d}$ prior to slaughter. The cattle were fed on timed feeders that delivered feed every $2 \mathrm{~h}$. Immediately following slaughter, the abomasum was isolated, and the contents of the abomasum were collected. These contents were freezedried, ground to pass a $1-\mathrm{mm}$ screen, and analyzed for $\mathrm{N}$ content with the macro-Kjeldahl method (AOAC, 1984). To determine amino acid composition, samples were hydrolyzed in $6 \mathrm{~N} \mathrm{HCl}$, and amino acid content of hydrolyzates was determined by ion-exchange chromatography (AOAC, 1984). Separate samples were oxidized with performic acid for analysis of Cys and Met (AOAC, 1984). All analyses were conducted in duplicate.

Metabolizable protein flow for steers at maximum gain in the finishing trial was predicted using Level 1 of the NRC model (1996) for ruminant protein metabolism. Flow of individual metabolizable amino acids was calculated by multiplying the predicted MP supply (NRC, 1996) by the abomasal amino acid composition as a percentage of the protein $(\mathrm{N} \times 6.25)$. All experiments were approved by the Institutional Animal Care and Use Committee.

\section{Results and Discussion}

Finishing Trial. Daily gain, feed intake, and feed efficiency were not different between steers fed the negative control diet and those supplemented with rumenprotected Met (Table 2). However, plasma Met concentrations were elevated in steers supplemented with rumen-protected Met $(P<.05$, Tables 4 and 5$)$. This elevation of plasma Met concentration is evidence that the rumen-protected Met was available postruminally and absorbed by the animals, as reported by Polan et al.
(1991). However, the lack of a performance response suggested that Met was not the first- limiting amino acid in steers finished on diets containing large amounts of corn protein. These results were expected, because corn protein contains substantial amounts of Met (NRC, 1996). Hill et al. (1980) also reported no increase in $\mathrm{N}$ retention in steers fed diets containing 65\% corn when Met was infused postruminally.

For the full $161 \mathrm{~d}$ of the trial, there were no treatment effects for ADG, DMI, or gain:feed ratio (Table 2). Metabolizable protein requirement decreases as cattle increase in body weight and degree of fattening (NRC, 1996). Therefore, statistical analysis was conducted on the different time periods in the trial. A significant $(P$ $<.05$ ) treatment effect for ADG or gain:feed ratio was found only in the first 56-d period. This is the time period when the metabolizable protein requirement and protein deposition are greatest. There was no response to Met during the first $56 \mathrm{~d}$, and there was a quadratic response to Lys for ADG $(P<.01)$ and gain:feed ratio $(P<.02)$. The 3 and $4 \mathrm{~g} / \mathrm{d}$ amounts of Lys increased ADG by $.28 \mathrm{~kg} / \mathrm{d}$, but there was no increase at the highest level of Lys, thus the quadratic response. Gain:feed ratio followed a similar response, except that the $1 \mathrm{~g} / \mathrm{d}$ amount of Lys gave a response similar to the 3 and $4 \mathrm{~g} / \mathrm{d}$ amounts.

Lysine supplementation, however, failed to increase plasma Lys concentration $(P>.30$; Tables 3,4 , and 5$)$. The improvement in performance is evidence that the rumen-protected Lys was available postruminally and absorbed by the animals. Klemesrud et al. (2000) obtained a response to this same product in growing calves. The increased plasma Met indicates that the coating was effective. The gain response also suggests that Lys was the first-limiting amino acid in steers finished on diets containing large amounts of corn protein. Increased $\mathrm{N}$ retention has been reported in steers consuming diets high in corn when abomasally infused with Lys (Burris et al., 1973; Hill et al., 1980; Titgemeyer et al., 1988). Burris et al. (1973) observed a quadratic effect of Lys infusion on $\mathrm{N}$ retention, similar to our observation.

Performance responses to supplemental rumen-protected Lys did not exist for any period beyond d 56 . Any differences in body weight could be attributed to differences obtained during the first $56 \mathrm{~d}$ on feed. By the conclusion of the trial, overall daily gain and efficiency of gain were not statistically different (Table 2). However, a numerical advantage existed in ADG and efficiency of gain for steers supplemented with 3 to 4 $\mathrm{g} / \mathrm{d}$ of rumen-protected Lys. The steers supplemented with 3 to $4 \mathrm{~g} / \mathrm{d}$ Lys had a weight advantage of $16 \mathrm{~kg}$ after $56 \mathrm{~d}$ on feed. This weight advantage increased to $32 \mathrm{~kg}$ by the end of the trial.

Nonlinear analysis comparing 56-d ADG to supplemental Lys intake predicted a breakpoint at $2.56 \mathrm{~g}$ Lys, which resulted in an $\mathrm{ADG}$ of $2.10 \mathrm{~kg} / \mathrm{d}$. Addition of rumen-protected Lys in excess of $2.56 \mathrm{~g} / \mathrm{d}$ did not further improve ADG. The $12 \mathrm{~g} / \mathrm{d}$ level of Lys was omitted from 
Table 2. Effect of supplemental lysine and methionine on finishing calf performance

\begin{tabular}{|c|c|c|c|c|c|c|c|c|c|c|c|}
\hline Item & 0 & 1 & 2 & 3 & 4 & 6 & 8 & 10 & 12 & $0^{\mathrm{a}}$ & SEM \\
\hline \multicolumn{12}{|l|}{ Days 1 to 56} \\
\hline DMI, kg & 8.66 & 8.59 & 8.74 & 8.90 & 9.28 & 8.85 & 9.16 & 9.07 & 8.36 & 8.70 & .43 \\
\hline $\mathrm{ADG}, \mathrm{kg}^{\mathrm{bc}}$ & 1.83 & 1.99 & 1.92 & 2.10 & 2.12 & 2.06 & 2.04 & 2.10 & 1.80 & 1.82 & .13 \\
\hline ADG:DMI ${ }^{\mathrm{d}}$ & .210 & .232 & .217 & .236 & .229 & .232 & .222 & .232 & .216 & 2.09 & .009 \\
\hline \multicolumn{12}{|c|}{ Days 57 to 161} \\
\hline ADG:DMI & .180 & .178 & .191 & .183 & .183 & .167 & .178 & .176 & .174 & .181 & .008 \\
\hline \multicolumn{12}{|c|}{ Days 1 to 161} \\
\hline DMI, kg & 9.22 & 8.92 & 8.61 & 9.60 & 9.97 & 9.63 & 9.53 & 9.77 & 9.02 & 9.15 & .45 \\
\hline $\mathrm{ADG}, \mathrm{kg}$ & 1.75 & 1.75 & 1.73 & 1.92 & 1.97 & 1.81 & 1.84 & 1.89 & 1.69 & 1.74 & .10 \\
\hline ADG:DMI & .190 & .197 & .201 & .200 & .198 & .189 & .193 & .194 & .188 & .190 & .007 \\
\hline
\end{tabular}

${ }^{\mathrm{a}}$ Methionine control.

${ }^{\mathrm{b}}$ Quadratic $(P=.01)$.

${ }^{\mathrm{c}} \mathrm{NLIN}$ predicted a plateau at $2.56 \mathrm{~g} / \mathrm{d}$ lysine (using levels 0 through 10 ) at .26 kg/d gain above control.

${ }^{\mathrm{d}}$ Quadratic $(P=.02)$.

Table 3. Plasma amino acid response to incremental amounts of rumen-protected lysine, d 28

\begin{tabular}{|c|c|c|c|c|c|c|c|c|c|c|c|}
\hline \multirow[b]{2}{*}{ Item $^{\mathrm{a}}$} & \multicolumn{10}{|c|}{ Supplemental Lys, g/d } & \multirow[b]{2}{*}{ SEM } \\
\hline & 0 & 1 & 2 & 3 & 4 & 6 & 8 & 10 & 12 & $0^{\mathrm{b}}$ & \\
\hline Lysine & .83 & .97 & 1.31 & 1.07 & .99 & .91 & .86 & .93 & 1.03 & 1.02 & .12 \\
\hline Methionine & .43 & .48 & .42 & .49 & .47 & .45 & .44 & .47 & .49 & .49 & .04 \\
\hline Histidine & .70 & .80 & .85 & .81 & .72 & .72 & .76 & .72 & .72 & .75 & .06 \\
\hline Phenylalanine & 1.07 & 1.07 & 1.04 & 1.10 & 1.11 & .96 & 1.02 & 1.13 & 1.10 & 1.04 & .07 \\
\hline Threonine & .97 & .96 & 1.13 & .96 & 1.03 & .86 & .95 & 1.01 & .88 & .81 & .09 \\
\hline Leucine & 2.48 & 2.43 & 2.67 & 2.47 & 2.70 & 2.27 & 2.54 & 2.49 & 2.50 & 2.43 & .14 \\
\hline Isoleucine & 1.25 & 1.25 & 1.38 & 1.26 & 1.37 & 1.17 & 1.28 & 1.26 & 1.27 & 1.27 & .08 \\
\hline Valine & 2.52 & 2.60 & 2.97 & 2.58 & 2.78 & 2.39 & 2.71 & 2.56 & 2.53 & 2.53 & .16 \\
\hline Arginine & 1.44 & 1.43 & 1.60 & 1.67 & 1.60 & 1.41 & 1.37 & 1.43 & 1.46 & 1.56 & .12 \\
\hline Tryptophan & .57 & .66 & .66 & .73 & .66 & .67 & .61 & .56 & .51 & .56 & .06 \\
\hline
\end{tabular}

${ }^{a}$ Least squares means concentrations $(\mathrm{mg} / 100 \mathrm{~mL})$.

${ }^{\mathrm{b}}$ Methionine control.

Table 4. Plasma amino acid response to incremental amounts of rumen-protected lysine, d 56

\begin{tabular}{|c|c|c|c|c|c|c|c|c|c|c|c|}
\hline \multirow[b]{2}{*}{ Item $^{\mathrm{a}}$} & \multicolumn{10}{|c|}{ Supplemental Lys, g/d } & \multirow[b]{2}{*}{ SEM } \\
\hline & 0 & 1 & 2 & 3 & 4 & 6 & 8 & 10 & 12 & $0^{\mathrm{b}}$ & \\
\hline Lysine & 1.14 & 1.25 & 1.37 & 1.27 & 1.45 & 1.02 & 1.25 & 1.36 & 1.43 & 1.42 & .14 \\
\hline Methionine $^{c}$ & .35 & .40 & .38 & .37 & .44 & .37 & .37 & .41 & .36 & .74 & .18 \\
\hline Histidine & .73 & .83 & .80 & .82 & .85 & .82 & .80 & .84 & .83 & .79 & .05 \\
\hline Phenylalanine & .93 & .93 & 1.00 & .91 & .96 & .85 & .90 & 1.01 & .96 & .93 & .05 \\
\hline Threonine & .81 & .84 & 1.02 & .83 & .95 & .73 & .86 & .99 & .95 & .85 & .08 \\
\hline Leucine & 2.64 & 2.81 & 2.99 & 2.66 & 2.95 & 2.72 & 2.85 & 3.01 & 3.00 & 2.98 & .30 \\
\hline Isoleucine & 1.31 & 1.41 & 1.45 & 1.28 & 1.54 & 1.28 & 1.41 & 1.50 & 1.44 & 1.48 & .12 \\
\hline Valine & 2.68 & 2.85 & 3.20 & 2.76 & 3.15 & 2.83 & 2.86 & 3.01 & 3.19 & 3.32 & .40 \\
\hline Arginine & 1.40 & 1.45 & 1.40 & 1.45 & 1.66 & 1.30 & 1.47 & 1.51 & 1.49 & 1.41 & .08 \\
\hline Tryptophan ${ }^{\mathrm{d}}$ & .55 & .69 & .71 & .78 & .76 & .72 & .65 & .66 & .65 & .64 & .07 \\
\hline
\end{tabular}

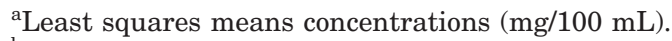

${ }^{\mathrm{b}}$ Methionine control.

${ }^{\mathrm{c}}$ Negative control vs Met control, $P<.05$. 
Table 5. Plasma amino acid response to incremental amounts of rumen-protected lysine, d 140

\begin{tabular}{|c|c|c|c|c|c|c|c|c|c|c|c|}
\hline \multirow[b]{2}{*}{ Item $^{\mathrm{a}}$} & \multicolumn{10}{|c|}{ Supplemental Lys, g/d } & \multirow[b]{2}{*}{ SEM } \\
\hline & 0 & 1 & 2 & 3 & 4 & 6 & 8 & 10 & 12 & $0^{\mathrm{b}}$ & \\
\hline Lysine & 1.01 & 1.09 & 1.24 & 1.13 & 1.31 & 1.12 & 1.10 & 1.16 & 1.43 & 1.25 & .15 \\
\hline Methionine $e^{c}$ & .37 & .40 & .48 & .38 & .47 & .50 & .42 & .41 & .44 & .50 & .03 \\
\hline Histidine & .66 & .78 & .77 & .73 & .76 & .89 & .75 & .74 & .75 & .71 & .05 \\
\hline Phenylalanine & .86 & .83 & .94 & .87 & .91 & .86 & .78 & .86 & .92 & .89 & .05 \\
\hline Threonine $^{c}$ & .71 & .76 & .83 & .78 & .91 & .87 & .72 & 1.00 & .89 & .73 & .08 \\
\hline Leucine & 1.79 & 2.00 & 2.08 & 1.94 & 2.23 & 2.24 & 2.00 & 1.99 & 2.46 & 1.90 & .18 \\
\hline Isoleucine & 1.02 & 1.12 & 1.14 & 1.09 & 1.22 & 1.18 & 1.12 & 1.14 & 1.34 & 1.15 & .10 \\
\hline Valine $^{c}$ & 2.15 & 2.32 & 2.40 & 2.34 & 2.70 & 2.71 & 2.39 & 2.48 & 2.88 & 2.33 & .20 \\
\hline Arginine & 1.24 & 1.12 & 1.37 & 1.49 & 1.33 & 1.26 & 1.50 & 1.13 & 1.43 & 1.18 & .17 \\
\hline Tryptophan & .62 & .73 & .69 & .77 & .78 & .80 & .76 & .68 & .74 & .72 & .07 \\
\hline
\end{tabular}

${ }^{\mathrm{a}}$ Least squares mean concentrations $(\mathrm{mg} / 100 \mathrm{~mL})$.

${ }^{\mathrm{b}}$ Methionine control.

${ }^{\mathrm{c}}$ Linear, $P<.05$.

the analysis because NLIN analysis assumes a plateau. The $12 \mathrm{~g} / \mathrm{d}$ level of Lys was below the maximum gain (plateau) and resulted in a quadratic effect. With the $12 \mathrm{~g} / \mathrm{d}$ level of Lys included in the NLIN analysis, the breakpoint was at 2.53. Nonlinear analysis did not converge on a breakpoint using gain:feed ratio because maximum efficiency was achieved at or below the lowest level of added Lys. That analysis would predict a Lys requirement 1.6 to $2.5 \mathrm{~g} / \mathrm{d}$ less than that predicted by ADG. Nonlinear analyses evaluating periods of the trial beyond $56 \mathrm{~d}$ are not reported because performance criteria were not different beyond $d 56$.

Following slaughter, there were no differences in hot carcass weight or quality grade (Table 6), although the addition of 3 to $4 \mathrm{~g}$ of rumen-protected Lys did seem to have a numerical advantage in carcass weight. Steers consuming the Met control diet had a greater 12th rib fat thickness and yield grade than the negative control $(P<.10)$.

Metabolism Trial. Amino acid composition of protein present in the abomasum was determined (Table 7). These values represent the amino acid composition of the microbial protein as well as the dietary protein from the basal diet that escapes ruminal degradation. Although the microbial protein supply is a function of the dietary TDN (Burroughs et al., 1974), its amino acid composition is similar among different cattle and differ- ent diets (Burris et al., 1973; Storm et al., 1983). The $\mathrm{MP}$ and amino acid supply from the basal diet, however, is a function of the escape protein value of the feedstuffs in the basal diet as well as their amino acid contents.

Level 1 of the NRC Model (1996) predicted MP supply to be less than the requirement during the first $56 \mathrm{~d}$. The MP flow to the small intestine for a $290-\mathrm{kg}$ steer (average BW between d 0 to 56) gaining $2.10 \mathrm{~kg} / \mathrm{d}$ (maximum gain) was $715 \mathrm{~g}$ (NRC, 1996; Table 8). Based on the amino acid composition of abomasal contents and the amount of rumen-protected Lys supplemented to maximize ADG, the metabolizable Lys requirement was $40.5 \mathrm{~g} / \mathrm{d}$ (Table 8). The estimated Lys requirement of $40.5 \mathrm{~g} / \mathrm{d}$ is similar to the requirement $(41.1 \mathrm{~g} / \mathrm{d})$ reported by the NRC (1996). The NRC value is based on the amino acid content of whole empty-body protein and efficiencies of .85 or .66. Heger and Frydrych (1989) reported that each amino acid has a unique efficiency factor depending on the biological value of the protein and the amino acid supply relative to its requirement. A limiting amino acid may have a greater efficiency, thus increasing its utilization relative to other amino acids.

Based on the amino acids supplied, Lys, Met, and His are similar to the requirements (NRC, 1996). We have determined Lys to be first-limiting, which suggests that Met and(or) His may become next-limiting.

Table 6. Effect of supplemental lysine and methionine on carcass characteristics

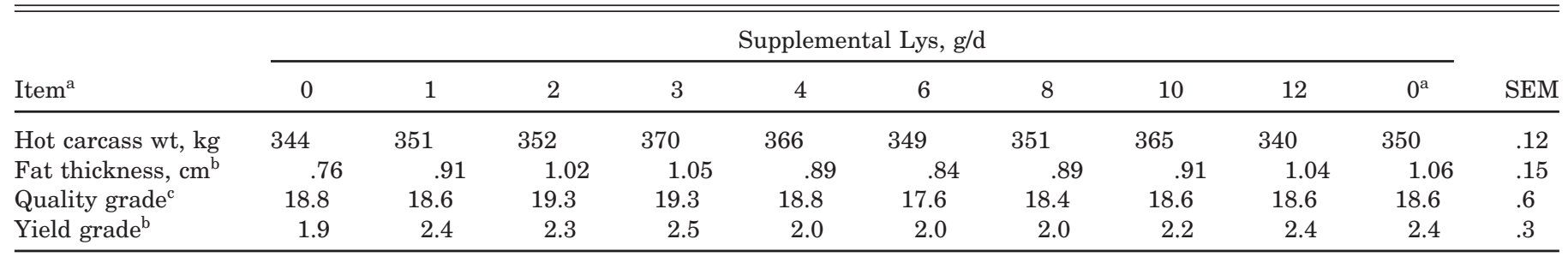

${ }^{a}$ Methionine control.

${ }^{\mathrm{b}}$ Negative control vs Met control, $P<.10$.

'Quality grade; $18=$ high Select, $19=$ low Choice. 
Table 7. Amino acid composition of abomasal protein ${ }^{\mathrm{a}}$

\begin{tabular}{lc}
\hline \hline Amino acid & \% of Crude protein \\
\hline Lysine & $5.30 \pm .85$ \\
Methionine & $1.54 \pm .22$ \\
Histidine & $2.27 \pm .12$ \\
Phenylalanine & $4.37 \pm .14$ \\
Threonine & $4.68 \pm .38$ \\
Leucine & $9.34 \pm .57$ \\
Isoleucine & $3.76 \pm .09$ \\
Valine & $4.88 \pm .49$ \\
Arginine & $5.43 \pm 1.34$ \\
Cystine & $2.43 \pm .38$ \\
TSAA $^{\mathrm{c}}$ & $3.97 \pm .52$ \\
\hline
\end{tabular}

${ }^{\mathrm{a} C o l l e c t e d ~ i m m e d i a t e l y ~ f o l l o w i n g ~ s l a u g h t e r ~ o f ~ s t e e r s ~ c o n s u m i n g ~ t h e ~}$ basal diet.

${ }^{\mathrm{b}}$ Mean $\pm \mathrm{SD}, \mathrm{n}=4$.

'Total sulfur amino acids (Met + cystine).

The amounts of total sulfur amino acids supplied may be adequate to meet the requirement, which suggests His may be next-limiting.

The use of ruminally protected amino acids has been investigated as a method of improving performance of growing-finishing beef cattle (Oke et al., 1986; Wright and Loerch, 1988; Hussein and Berger, 1995). However, results of growth studies have been variable. In order to elicit a production response, the supplemented amino acid must also be the amino acid limiting performance. Determination of metabolizable amino acid require-

Table 8. Metabolizable protein and amino acids supplied to finishing steers for maximum gain compared with predicted requirements during the first $56 \mathrm{~d}$ on feed ${ }^{\mathrm{a}}$

\begin{tabular}{|c|c|c|c|c|}
\hline \multirow[b]{2}{*}{ Item } & \multicolumn{2}{|c|}{ Amino acid source } & \multirow[b]{2}{*}{$\begin{array}{l}\text { Total, } \\
\text { g/d }\end{array}$} & \multirow[b]{2}{*}{$\begin{array}{l}\text { Requirement, } \\
\mathrm{g} / \mathrm{d}^{\mathrm{c}}\end{array}$} \\
\hline & $\begin{array}{l}\text { Basal } \\
\text { diet }^{\mathrm{b}}\end{array}$ & $\begin{array}{l}\text { Added Lys } \\
\text { and Met }\end{array}$ & & \\
\hline $\begin{array}{l}\text { Metabolizable } \\
\text { protein }^{\mathrm{d}}\end{array}$ & 715 & - & - & 868 \\
\hline Lysine & 37.9 & 2.56 & 40.5 & 41.1 \\
\hline Methionine & 11 & .8 & 11.8 & 12.8 \\
\hline Histidine & 16.2 & - & 16.2 & 16.1 \\
\hline Phenylalanine & 31.2 & - & 31.2 & 22.5 \\
\hline Threonine & 33.5 & - & 33.5 & 25.0 \\
\hline Leucine & 66.8 & - & 66.8 & 50.3 \\
\hline Isoleucine & 26.9 & - & 26.9 & 21.0 \\
\hline Valine & 34.9 & - & 34.9 & 30.0 \\
\hline Arginine & 38.8 & - & 38.8 & 24.8 \\
\hline Cystine & 17.4 & - & 17.4 & $12.8^{\mathrm{e}}$ \\
\hline TSAA $^{\mathrm{f}}$ & 29.2 & - & 29.2 & 25.6 \\
\hline
\end{tabular}

${ }^{\text {a}}$ Expressed as grams/day of metabolizable protein and amino acids flowing to the small intestine for steers at maximum gain $(2.10 \mathrm{~kg} /$ d). Based on a 290-kg animal (average BW between d 0 to 56).

${ }^{\mathrm{b}}$ Calculated from MP supply and amino acid analysis from Table 7.

${ }^{\mathrm{c}}$ Requirement based on Level 1 NRC (1996).

${ }^{\mathrm{d}}$ Metabolizable protein supply (MP) calculated from Level 1 of NRC (1996) model.

'Based on Ahmed and Bergen (1983), in which cystine can supply $50 \%$ of the sulfur amino acid requirement.

fTotal sulfur amino acids (Met and cystine). ments for ruminants will allow evaluation of diets to determine which amino acid is limiting performance. Balancing of diets for metabolizable amino acids will then maximize animal performance and efficiency of protein utilization.

\section{Implications}

The amino acid composition of protein reaching the small intestine of steers fed diets high in corn but low in escape protein may be deficient in metabolizable lysine. Addition of rumen-protected lysine to corn-based finishing diets can improve $\mathrm{ADG}$ of steers, especially early in the feeding period. By meeting the animal's requirement for amino acids without overfeeding, efficiency of protein utilization can be maximized. This increased efficiency would decrease nitrogen excretion and consequently the evolution of $\mathrm{NH}_{3}$ into the environment. The lysine requirement for a $209-\mathrm{kg}$ calf gaining $2.10 \mathrm{~kg} / \mathrm{d}$ was $40.5 \mathrm{~g} / \mathrm{d}$.

\section{Literature Cited}

Ahmed, B. M., and W. G. Bergen. 1983. Methionine - cyst(e)ine relationship in steers. J. Anim. Sci. 57(Suppl. 1):110 (Abstr.).

AOAC. 1984. Official Methods of Analysis (13th Ed.). Association of Official Analytical Chemists, Washington, DC.

Burris, W. R., N. W. Bradley, and J. A. Boling. 1973. Effect of dietary nitrogen on in vitro release of microbial amino acids. J. Anim. Sci. 36:219 (Abstr.).

Burroughs, W., A. H. Trenkle, and R. L. Vetter. 1974. A system of protein evaluation for cattle and sheep involving metabolizable protein (amino acids) and urea fermentation potential of feedstuffs. Vet. Med. Small Anim. Clin. 69:713-722.

Byers, F. M., and R. E. Rompala. 1980. Level of energy effects on patterns and energetic efficiency of tissue deposition in small or large mature-size beef cattle. In: Energy Metabolism. EAAP. Publ. No. 26. pp 141 146. Butterworth's, London.

Firkins, J. L., L. L. Berger, G. C. Fahey, Jr., and N. R. Merchen. 1984. Ruminal nitrogen degradability and escape of wet and dry distillers grains and wet and dry corn gluten feeds. J. Dairy Sci. 67:1936-1944.

Gibb, D. J., T. J. Klopfenstein, R. A. Britton, and A. J. Lewis. 1992. Plasma amino acid response to graded levels of escape protein. J. Anim. Sci. 70:2885-2892.

Heger, J., and Z. Frydrych. 1989. Efficiency of utilization of amino acids. In: M. Friedman (Ed.) Absorption and Utilization of Amino Acids. Vol. 1. CRC Press, Boca Raton, FL.

Hill, G. M., J. A. Boling, and N. W. Bradley. 1980. Postruminal lysine and methionine infusion in steers fed a urea-supplemented diet adequate in sulfur. J. Dairy Sci. 63:1242-1247.

Hussein, H. S., and L. L. Berger. 1995. Feedlot performance and carcass characteristics of Holstein steers as affected by source of dietary protein and level of ruminally protected lysine and methionine. J. Anim. Sci. 73:3503-3509.

Klemesrud, M. J., T. J. Klopfenstein, and A. J. Lewis. 2000. Metabolizable methionine and lysine requirements of growing cattle. J. Anim. Sci. 78:199-206.

Klopfenstein, T., R. Stock, and R. Britton. 1985. Relevance of bypass protein to cattle feeding. Prof. Anim. Sci. 1:27-31.

Komarek, R. J., R. A. Jandzinski, and S. R. Ames. 1983. Effect of diet upon the postruminal supplies of amino acids in the steer. J. Anim. Sci. 57(Suppl. 1):447-448 (Abstr.).

McCoy, R. A., R. A. Stock, T. J. Klopfenstein, D. H. Shain, and M. J. Klemesrud. 1998. Effect of energy source and escape protein on receiving and finishing performance and health of calves. J. Anim. Sci. 76:1488-1498. 
Nimrick, E., E. E. Hatfield, J. Kaminske, and F. N. Owens. 1970. Quantitative assessment of supplemental amino acid needs for growing lambs fed urea as the sole nitrogen source. J. Nutr. 100:1301-1306.

NRC. 1996. Nutrient Requirements of Beef Cattle (7th Ed.). National Academy Press, Washington, DC.

Oke, B. O., S. C. Loerch, and L. E. Deetz. 1986. Effects of rumenprotected methionine and lysine on ruminant performance and nutrient metabolism. J. Anim. Sci. 62:1101-1112.

Polan, C. E., K. A. Cummins, C. J. Sniffen, T. V. Muscato, J. L. Vicini, B. A. Crooker, J. H. Clark, D. G. Johnson, D. E. Otterby, B. Guillaume, L. D. Muller, G. A. Varga, R. A. Murray, and S. B. Peirce-Sandner. 1991. Responses of dairy cows to supplemental rumen-protected forms of methionine and lysine. J. Dairy Sci. 74:2997-3013.

Richards, C. J., R. A. Stock, T. J. Klopfenstein, and D. H. Shain. 1998. Effect of wet corn gluten feed, supplemental protein, and tallow on steer finishing performance. J. Anim. Sci. 76:421-428.

SAS. 1985. SAS User's Guide: Statistics. SAS Inst. Inc., Cary, NC.
Sindt, M. H., R. A. Stock, T. J. Klopfenstein, and D. H. Shain. 1993a. Effect of protein source and grain type on finishing calf performance and ruminal metabolism. J. Anim. Sci. 71:1047-1056.

Sindt, M. H., R. A. Stock, T. J. Klopfenstein, and B. A. Vieselmeyer. 1993b. Protein sources for finishing calves as affected by management system. J. Anim. Sci. 71:740-752.

Storm, E., D. S. Brown, and E. R. Ørskov. 1983. The nutritive value of rumen micro-organisms in ruminants. I. Large scale isolation and chemical composition of rumen microorganisms. Br. J. Nutr. 50:463-470.

Titgemeyer, E. C., N. R. Merchen, L. L. Berger, and L. E. Deetz. 1988. Estimation of lysine and methionine requirements of growing steers fed corn silage-based or corn-based diets. J. Dairy Sci. 71:421-434.

Williams, A. P., and R. H. Smith. 1974. Concentrations of amino acids and urea in the plasma of the ruminating calf and estimation of the amino acid requirements. Br. J. Nutr. 32:421-433.

Wright, M. D., and S. C. Loerch. 1988. Effects of rumen-protected amino acids on ruminant nitrogen balance, plasma amino acid concentrations and performance. J. Anim. Sci. 66:2014-2027. 